\title{
POLA MAKAN DAN TINGKAT PENGETAHUAN GIZI TERHADAP RESIKO KEJADIAN OBESITAS PADA REMAJA DI SMA KRISTEN 1 TOMOHON.
}

\author{
I Made Djendra ${ }^{1}$,Langi Clift Christian Vincent ${ }^{2}$,Rudolf Boyke Purba ${ }^{3}$ \\ 1,2,3 Poltekes Kemenkes Manado \\ dedjendra@gmail.com
}

\begin{abstract}
Obest or obesity is the term used to show the accumulation of body fat that exceeds the normal limit. Excessive accumulation of body fat can often seem reluctant easily. People who are overweight are more receptive than normal weight people to external hunger cues, such as food taste and smell, or time to eat. Fat people tend to eat if they feel like eating, not eating when they are hungry.

The type of research used was analytic observational research with cross sectional design. The population in this study were all students at Tomohon Christian High School 1 which was 1063 students. The sample was calculated in Slovak with a total of 43 students. Primary data is data about diet and the level of nutritional knowledge collected directly during the research. In this study most have a moderate level of knowledge with a total of 20 people $(46.5 \%)$, a good level of knowledge of 20 people (32.6\%), and less knowledge level of 9 people (20.9\%).

The results of the analysis using statistical test fisherexacttest with a value of $p<0.05$, which means there is a significant relationship between intake of levels of nutritional knowledge with obesity.
\end{abstract}

\section{Keywords: Obesity, Eating Patterns, Intake of Energy, Protein, Fat, Carbohydrate}

\section{PENDAHULUAN}

Peningkatan pendapatan pada kelompok masyarakat tertentu, terutama di perkotaan menyebabkan perubahan dalam gaya hidup, terutama dalam pola makan. Pola makan tradisional yang tadinya tinggi katbohidrat, tinggi serat kasar, dan rendah lemak, berubah ke pola makan baru yang rendah karbohidrat, rendah serat kasar, dan tinggi lemak sehingga menggeser mutu makanan ke arah tidak seimbang.Perubahan pola makan ini dipercepat oleh makin kuatnya arus budaya makanan asing yang disebabkan oleh kemajuan teknologi informasi dan globalisasi ekonomi (Almatsier, 2010).

Obesitas atau kegemukan adalah istiah yang digunakan untuk menunjukan adanya penumpukan lemak tubuh yang malebihi batas normal.Penumpukan lemak tubuh yang berlebihan itu sering dapat terlihat enggan mudah. Secara praktis digunakan ukuran berupa perbandingan berat badan terhadap berat badan baku untuk ukuran tinggi tubuh tertentu (Suiraoka, 2012)

Orang yang kegemukan lebih resonsif dibanding dengan orang berberat badan normal terhadap isyarat lapar eksternal, seperti rasa dan bau makanan, atau saatnya waktu makan. Orang yang gemuk cenderung makan bila ia merasa ingin makan, bukan makan pada saat ia lapar Pola makan berlebih inilah yang menyebabkan gv mereka sulit untuk keluar dari kegemukan jika sang individu tidakmemiliki kontrol diri dan motivasi yang kuat untuk mengurangi berat badan

Etnis Minahasa mempunyai suatu kebiasanbudaya 'pesta' dalam pengertian disini adalah kebiasaan rnakan makan 'enak' atau mengkonsumsi makanan yang mengandungasam lemakjenuh tinggi seperti 'babi putar', tinorangsak, RW (anjing), pangi, 
babi dan sebagainya (Kandou, 2009). Hasil dari penelitian pada remaja di Kabupaten Minahasa menunjukkan bahwa prevalensi obesitas sebesar $26,33 \%$ yang terdiri dari $4,30 \%$ remaja perempuan dan 22,03\% remaja laki-laki(Kussoy dkk, 2013).

Saat ini lebih suka mengkonsumsi makanan berlemak, sehingga dapat memicu naiknya berat badan mereka.Seperti pada penelitian yang dilakukan pada remaja obesitas dan non obesitas menunjukkan bahwa sebagian besar(60\%) tingkat pengetahuan gizi remaja pada kelompok obesitas adalah kurang, sedangkan $85 \%$ remaja pada kelompok non obesitas memiliki pengetahuan gizi yang cukup (Suryaputra dan Nadhiroh, 2012).

\section{METODE}

Jenispenelitian yang digunakan yaitu penelitian Observasional analitik dengan desain Cross sectional. Penelitian ini dilakukan pada bulan Maret tahun 2017 sampai dengan bulan Mei tahun 2017 pada sekolah SMA Kristen 1 Tomohon. pada penelitian ini adalah pola makan dan pengetahuan gizi sedangkan variable terikat (dependent variable) adalah obesitas pada siswa sekolah menengah atas (SMA) .

\section{HASIL}

a. Karakteristik Sampel

1) Jenis Kelamin

Hasil analisis menunjukan bahwa responden berjenis kelamin laki-laki lebih besar persentase obesitasnya yaitu sebesar $37.2 \%$.

Tabel 2. Distribusi Responden Menurut Jenis Kelamin

\begin{tabular}{cccccccc}
\hline \multirow{2}{*}{ Satus Gizi } & \multicolumn{4}{c}{ JenisKelamin } & \multicolumn{2}{c}{ Total } \\
\cline { 2 - 5 } & \multicolumn{2}{c}{ Laki-laki } & \multicolumn{2}{c}{ Perempuan } & & \\
& $\mathrm{n}$ & $(\%)$ & $\mathrm{n}$ & $(\%)$ & & $\mathrm{n}$ & $(\%)$ \\
\hline Non obesitas & 5 & 11.6 & 8 & 18.6 & & 13 & 30.2 \\
Obesitas & 16 & 37.2 & 14 & 32.6 & & 30 & 69.8 \\
\hline Total & 21 & 48.8 & 22 & 51.2 & & 43 & 100 \\
\hline
\end{tabular}

2) Umur

Hasil anaisis menunjukan bahwa sebagian besar responden pada usia 16 tahun memiliki persentase obesitas yang lebih besar yaitu $79.11 \%$.

Tabel 3. Distribusi Responden Menurut Umur

\begin{tabular}{|c|c|c|c|c|c|c|c|}
\hline \multirow{3}{*}{ Status Gizi } & \multicolumn{5}{|c|}{ Umur (thn) } & \multirow{2}{*}{\multicolumn{2}{|c|}{ Total }} \\
\hline & 15 & \multicolumn{2}{|c|}{16} & \multicolumn{2}{|c|}{17} & & \\
\hline & $\%$ & $\mathrm{n}$ & $\%$ & $\mathrm{n}$ & $\%$ & $\mathrm{n}$ & $\%$ \\
\hline Non Obesitas & 00 & & 27.9 & & 2.3 & 13 & 30.2 \\
\hline Obesitas & 24.7 & 22 & 51.2 & 6 & 14 & 30 & 69.8 \\
\hline Total & 24.7 & 34 & 79.1 & 7 & 16.3 & & 100 \\
\hline
\end{tabular}




\section{3) Berat Badan}

Hasil analisis menunjukan bahwa responden pada rentang berat badan $70 \mathrm{~kg}-89 \mathrm{~kg}$ memiliki jumah yang lebih banyak dibandingkan yang lainnya yaitu sebesar 18 orang.

Tabel 4. Distribusi Responden Menurut Berat Badan

\begin{tabular}{ccc}
\hline BeratBadan $(\mathrm{kg})$ & $\mathrm{n}$ & $\%$ \\
\hline $50-69$ & 7 & 16.3 \\
$70-89$ & 18 & 41.9 \\
$90-109$ & 15 & 34.9 \\
$110-129$ & 3 & 7.0 \\
\hline Total & 43 & 100 \\
\hline
\end{tabular}

4) Tinggi Badan

Hasil analisis menunjukan bahwa responden dengan rentang tinggi badan $1.60 \mathrm{~m}-$ $1.79 \mathrm{~m}$ memiliki jumlah yang lebih besar yaitu 31 orang (72.1\%) dibandingkan dengan yang lain .

Tabel 5. Distrbusi Responden Menurut Tinggi Badan

\begin{tabular}{ccc}
\hline Tinggibadan $(\mathrm{m})$ & $\mathrm{n}$ & $\%$ \\
\hline $1.40-1.59$ & 11 & 25.6 \\
$1.60-1.79$ & 31 & 72.1 \\
$1.80-1.99$ & 1 & 2.3 \\
\hline Total & 43 & 100 \\
\hline
\end{tabular}

5) Tingkat Pengetahuan Gizi

Hasil analisis menunjukkan bahwa responden dalam penelitian ini sebagian besar memiliki tingkat pengetahuan yang sedang dengan jumlah 20 orang (46.5\%), tingkat pengetahuan baik 20 orang $(32.6 \%)$, dan tingkat pengeahuan kurang sebanyak 9 orang $(20.9 \%)$

Tabel 6. Disitribusi Responden Menurut Tingkat Pengetahuan Gizi

\begin{tabular}{ccc}
\hline Tingkat PengetahuanGizi & N & $\%$ \\
\hline Baik & 14 & 32.6 \\
Sedang & 20 & 46.5 \\
Kurang & 9 & 20.9 \\
\hline Total & 43 & 100 \\
\hline
\end{tabular}

6) Pola Makan

1. Jenis Makanan dan Frekuensi Makan Yang Dikonsumsi

Hasil analisis menunjukkan bahwa responden lebih sering mengkonsumsi sumber karbohidrat yaitu nasi 43 orang (100\%). 
Tabel 7. Distribusi Reponden Menurut Jenis dan Frekuensi Makan Sumber Karbohidrat

\begin{tabular}{|c|c|c|c|c|c|c|}
\hline \multirow[b]{2}{*}{ JenisMakanan (Karbohidrat) } & \multicolumn{4}{|c|}{ Frekuensi } & \multicolumn{2}{|c|}{ Jumlah } \\
\hline & \multicolumn{2}{|c|}{ Sering } & \multicolumn{2}{|c|}{ Jarang } & & $\begin{array}{l}\text { lah } \\
\%\end{array}$ \\
\hline Karbohidrat & & & & & & \\
\hline Nasi & 43 & 100 & 00 & & 43 & 100 \\
\hline Singkong & 24. & 7 & 41 & 95.3 & 43 & 100 \\
\hline Roti Putih & 23 & 53.5 & 20 & 46.5 & 43 & 100 \\
\hline Jagung & 15 & 34.9 & 28 & 65.1 & 43 & 100 \\
\hline
\end{tabular}

Hasil analisis menunjukkan bahwa responden lebih sering mengkonsumsi sumber protein yaitu ikan segar 40 orang (93\%), daging babi 25 orang (58.1\%), daging ayam 28 orang $(65.1 \%)$, telur ayam 26 orang $(60.5 \%)$.

Tabel 8. Distribusi Responden Menurut Jenis dan Frekuensi Makan Sumber Protein Hewani

\begin{tabular}{|c|c|c|c|c|c|c|}
\hline \multirow{4}{*}{$\begin{array}{c}\text { JenisMakanan (Protein Hewani) } \\
\text { Protein Hewani }\end{array}$} & \multicolumn{4}{|c|}{ Frekuensi } & \multirow{2}{*}{\multicolumn{2}{|c|}{ Jumlah }} \\
\hline & \multirow{2}{*}{\multicolumn{2}{|c|}{$\begin{array}{c}\text { Sering } \\
n \%\end{array}$}} & \multirow{2}{*}{\multicolumn{2}{|c|}{$\begin{array}{c}\text { Jarang } \\
n \%\end{array}$}} & & \\
\hline & & & & & \multicolumn{2}{|c|}{ n $\%$} \\
\hline & $\Delta 0$ & 93 & 3 & 7 & 13 & 100 \\
\hline IkanAsin & 12 & 3 & 31 & 97.7 & 43 & 100 \\
\hline Udang & 0 & 0 & 43 & 100 & 43 & 100 \\
\hline Bakso & 29 & 67.4 & 14 & 32.66 & 43 & 100 \\
\hline DagingBabi & 25 & 58.1 & 18 & 41.9 & 43 & 100 \\
\hline DagingSapi & 3 & 7 & 40 & 93 & 43 & 100 \\
\hline DagingAyam & 28 & 65.1 & 15 & 34.9 & 43 & 100 \\
\hline TelurAyam & 26 & 60.5 & 17 & 39.5 & 43 & 100 \\
\hline Nugget & 17 & 39.5 & 26 & 60.5 & 43 & 100 \\
\hline Sosis & 22 & 51.2 & 21 & 48.8 & 43 & 100 \\
\hline Keju & 16 & 37.2 & 27 & 62.8 & 43 & 100 \\
\hline
\end{tabular}

Hasil analisis menunjukkan bahwa responden lebih sering menkonsumsi sumber protein nabati yaitu tahu dan tempe sebanyak 43 orang (100\%).

Tabel 9. Distribusi Responden Menurut Jenis dan Frekuensi Makan Sumber Protein Nabati

\begin{tabular}{|c|c|c|c|c|c|c|}
\hline \multirow{3}{*}{$\begin{array}{c}\text { JenisMakanan (Protein Nabati) } \\
\text { Protein Nabati }\end{array}$} & \multicolumn{4}{|c|}{ Frekuensi } & \multirow{2}{*}{\multicolumn{2}{|c|}{ Jumlah }} \\
\hline & \multicolumn{2}{|c|}{$\begin{array}{c}\text { Sering } \\
\mathrm{n} \%\end{array}$} & \multicolumn{2}{|c|}{$\begin{array}{c}\text { Jarang } \\
\mathrm{n} \%\end{array}$} & & \\
\hline & & & & & & \\
\hline KacangHijau & 4 & 9.3 & 39 & 90.7 & 43 & 100 \\
\hline Kacang Tanah & 8 & 18.6 & 35 & 81.4 & 43 & 100 \\
\hline $\begin{array}{l}\text { Ianu } \\
\text { Tempe }\end{array}$ & 43 & 100 & 0 & 0 & $\begin{array}{l}43 \\
43\end{array}$ & 100 \\
\hline
\end{tabular}

Hasil analisis menunjukkan bahwa responden lebih sering menkonsumsi sayursayuran yaitu kangkung sebanyak 33 orang $(76.7 \%)$. 
Tabel 10. Distribusi Responden Menurut Jenis dan Frekuensi Makanan Sayur-sayuran

\begin{tabular}{|c|c|c|c|c|c|c|}
\hline \multirow{4}{*}{$\begin{array}{c}\text { JenisMakanan (Sayur-sayuran) } \\
\text { Sayur - sayuran }\end{array}$} & \multicolumn{4}{|c|}{ Frekuensi } & \multirow{2}{*}{\multicolumn{2}{|c|}{ Jumlah }} \\
\hline & \multirow{2}{*}{\multicolumn{2}{|c|}{$\begin{array}{c}\text { Sering } \\
n \%\end{array}$}} & \multirow{2}{*}{\multicolumn{2}{|c|}{$\begin{array}{c}\text { Jarang } \\
n \%\end{array}$}} & & \\
\hline & & & & & $\mathrm{n}$ & $\%$ \\
\hline & & & & & & \\
\hline Bayam & 5 & 11.6 & 38 & 88.4 & 43 & 100 \\
\hline Kangkung & 33 & 76.7 & 10 & 23.3 & 43 & 100 \\
\hline DaunSingkong & 6 & 14 & 37 & 86 & 43 & 100 \\
\hline SawiHijau & 14 & 32.6 & 29 & 67.4 & 43 & 100 \\
\hline Kol & 14 & 32.6 & 29 & 67.4 & 43 & 100 \\
\hline KembangKol & 9 & .9 & 34 & 79.1 & 43 & 100 \\
\hline Brokoli & 10 & 23.3 & 33 & 76.7 & 43 & 100 \\
\hline Timun & 19 & 44.2 & 24 & 55.8 & 43 & 100 \\
\hline KacangPanjang & 6 & 14 & 37 & 86 & 43 & 100 \\
\hline Buncis & 9 & 20.9 & 34 & 79.1 & 43 & 100 \\
\hline
\end{tabular}

Hasil analisis menunjukkan bahwa responden lebih sering menkonsumsi buah-buahan yaitu pepaya 28 orang $(65.1 \%)$ dan pisang 27 orang $(62.8 \%)$.

Tabel 11. Distribusi Responden Menurut Jenis dan Frekuensi Makanan Buah-Buahan

\begin{tabular}{|c|c|c|c|c|c|c|}
\hline \multirow{3}{*}{ JenisMakanan (Buah-buahan) } & \multicolumn{4}{|c|}{ Frekuensi } & \multirow{2}{*}{\multicolumn{2}{|c|}{ Jumlah }} \\
\hline & \multicolumn{2}{|c|}{ Sering } & \multicolumn{2}{|c|}{ Jarang } & & \\
\hline & $\mathrm{n}$ & $\%$ & $\mathrm{n}$ & $\%$ & $\mathrm{n}$ & $\%$ \\
\hline Buah - buahan & & & & & & \\
\hline Jeruk & 15 & 34.9 & 28 & 65.1 & 43 & 100 \\
\hline Pepaya & 28 & 65.1 & 15 & 34.9 & 43 & 100 \\
\hline Apel & 11 & 25.6 & 32 & 74.4 & 43 & 100 \\
\hline Pisang & 27 & 62.8 & 16 & 37.2 & 43 & 100 \\
\hline Mangga & 10 & 23.3 & 33 & 76.7 & 43 & 100 \\
\hline
\end{tabular}

Hasil analisis menunjukan bahwa responden lebih sering menkonsumsi camilan yaitu roti 25 orang $(58.1 \%)$.

Tabel 12. Distribusi Responden Menurut Jenis dan Frekuensi Makanan Camilan

\begin{tabular}{lrrrrrrr}
\hline \multirow{2}{*}{ JenisMakanan (Camilan) } & \multicolumn{4}{c}{ Frekuensi } & \multicolumn{3}{c}{ Jumlah } \\
\cline { 2 - 6 } & \multicolumn{2}{c}{ Sering } & \multicolumn{3}{c}{ Jarang } & & \\
& $\mathrm{n}$ & $\%$ & $\mathrm{n}$ & $\%$ & $\mathrm{n}$ & $\%$ \\
\hline Camilan & 19 & 44.2 & 24 & 55.8 & 43 & 100 \\
Donat & 5 & 11.6 & 38 & 88.4 & 43 & 100 \\
Yoghurt & 7 & 16.3 & 36 & 83.7 & 43 & 100 \\
Batagor & 25 & 58.1 & 18 & 41.9 & 43 & 100 \\
Roti & 6 & 14 & 37 & 86 & 43 & 100 \\
Puding & 4 & 9.3 & 39 & 90.7 & 43 & 100 \\
Coklat & 19 & 44.2 & 24 & 55.8 & 43 & 100 \\
Pop Ice & & & & & & \\
\hline
\end{tabular}

Hasil analisis menunjukan bahwa responden lebih sering menkonsumsi fast foodyaitu mie instan 25 orang (58.1\%) .

Tabel 13. Distribusi Responden Menurut Jenis dan Frekuensi Makanan Fast Food 


\begin{tabular}{|c|c|c|c|c|c|c|}
\hline \multirow{3}{*}{ JenisMakanan (Fast Food) } & \multicolumn{4}{|c|}{ Frekuensi } & & \\
\hline & \multirow{2}{*}{\multicolumn{2}{|c|}{$\begin{array}{c}\text { Sering } \\
\mathrm{n} \%\end{array}$}} & \multirow{2}{*}{\multicolumn{2}{|c|}{$\begin{array}{c}\text { Jarang } \\
\text { n \% }\end{array}$}} & \multicolumn{2}{|c|}{ Jumlah } \\
\hline & & & & & $\mathrm{n}$ & $\%$ \\
\hline Mielnstan & 25 & 58.1 & 18 & 41.9 & 43 & 100 \\
\hline Ice Cream & 21 & 48.8 & 22 & 51.2 & 43 & 100 \\
\hline Humburger & 8 & 18.6 & 35 & 81.4 & 43 & 100 \\
\hline Hotdog & 12 & 27.9 & 31 & 72.1 & 43 & 100 \\
\hline Pizza & 2 & 4.7 & 41 & 95.3 & 43 & 100 \\
\hline Fried Chiken & 17 & 39.5 & 26 & 60.5 & 43 & 100 \\
\hline Spaghetti & 2 & 4.7 & 41 & 95.3 & 43 & 100 \\
\hline French fried & 18 & 41.9 & 25 & 58.1 & 43 & 100 \\
\hline \multicolumn{7}{|l|}{ Soft Drink } \\
\hline Cocacola,Fanta,Sprite,Pepsi & \multicolumn{2}{|c|}{$\begin{array}{c}21 \\
48.8\end{array}$} & 22 & 51.2 & 43 & 100 \\
\hline
\end{tabular}

Hasil analisis menunjukan bahwa responden yang memiliki asupan zat gizi tinggi lebih banyak terdapat pada zat gizi energi $34(79.1 \%)$, protein $32(74.4 \%)$ dan karbohidrat $38(88.4 \%)$.

1. Konsumsi makanan sumber zat gizi makro Tabel 14. Distribusi Responden Menurut Asupan Zat Gizi Makro

\begin{tabular}{lccc}
\hline & Asupan & N & $\%$ \\
\hline Energi & & & \\
& Rendah & 9 & 20.9 \\
& Tinggi & 34 & 79.1 \\
\hline Protein & Total & 43 & 100 \\
& Rendah & & \\
& Tinggi & 11 & 25.6 \\
\hline Lemak & Total & 32 & 74.4 \\
& Rendah & 43 & 100 \\
& Tinggi & & \\
\hline Karbohidrat & Total & 28 & 65.1 \\
& Rendah & 15 & 100 \\
& Tinggi & 43 & 11.6 \\
\hline & Total & 5 & 88.4 \\
\hline
\end{tabular}

1. Hubungan Pola Makan dan Obesitas 
Hasil analisis menggunakan uji statistic fisherexacttestdengan nilaip $<0,05$ yaitu 0.000 yang berarti terdapat hubungan yang signifikan antara asupan energi dengan obesitas

Tabel 15. Analisis Hubungan Asupan Energi dan Obesitas

\begin{tabular}{ccccccccc}
\hline \multirow{3}{*}{ AsupanEnergi } & \multicolumn{4}{c}{ Status Gizi } & \multicolumn{2}{c}{ Total } & \multirow{2}{*}{-value } \\
\cline { 2 - 7 } & \multicolumn{2}{c}{ Non Obesitas } & \multicolumn{2}{c}{ Obesitas } & & \\
\cline { 2 - 6 } & $\mathrm{n}$ & $\%$ & $\mathrm{n}$ & $\%$ & $\mathrm{n}$ & $\%$ & \\
\hline Rendah & 8 & 18.6 & 1 & 2.3 & 9 & 20.9 & 0.000 \\
Tinggi & 5 & 11.6 & 29 & 67.4 & 34 & 79.1 & \\
\hline Total & 13 & 30.2 & 30 & 69.8 & 43 & 100 & \\
\hline
\end{tabular}

Hasil analisis menggunakan uji statistic fisherexacttestdengan nilaip<0,05yaitu 0.000 yang berarti terdapat hubungan yang signifikan antara asupan protein dengan obesitas.

Tabel 16. Analisis Hubungan Antara Asupan Protein dan Obesitas

\begin{tabular}{cccccccc}
\hline & \multicolumn{4}{c}{ Status Gizi } & \multicolumn{2}{c}{ Total } & \multirow{2}{*}{ p-value } \\
\cline { 2 - 6 } Asupan Protein & \multicolumn{2}{c}{ Non Obesitas } & \multicolumn{2}{c}{ Obesitas } & & & \\
\cline { 2 - 6 } & $\mathrm{n}$ & $\%$ & $\mathrm{n}$ & $\%$ & $\mathrm{n}$ & $\%$ & \\
\hline Rendah & 9 & 20.9 & 2 & 4.7 & 11 & 25.6 & 0.000 \\
Tinggi & 4 & 9.3 & 28 & 65.1 & 32 & 74.4 & \\
\hline Total & 13 & 30.2 & 30 & 69.8 & 43 & 100 & \\
\hline
\end{tabular}

Hasil analisis menggunakan uji statistikfisherexacttestdengan nilai $p<0,05$ yaitu 0.013yang berarti terdapat hubungan yang signifikan antara asupan lemak dengan obesitas. Tabel 17. Analisis Hubungan Antara Asupan Lemak dan Obesitas

\begin{tabular}{ccccccccc}
\hline & \multicolumn{3}{c}{ Status Gizi } & \multicolumn{2}{c}{ Total } & \multirow{2}{*}{$p$-value } \\
\cline { 2 - 5 } AsupanLemak & \multicolumn{2}{c}{ Non Obesitas } & \multicolumn{2}{c}{ Obesitas } & & \multicolumn{2}{c}{0.013} \\
\cline { 2 - 5 } & $\mathrm{n}$ & $\%$ & $\mathrm{n}$ & $\%$ & $\mathrm{n}$ & $\%$ & \\
\hline Rendah & 12 & 27.9 & 16 & 37.2 & 28 & 65.1 & \\
Tinggi & 1 & 2.3 & 14 & 32.6 & 15 & 34.9 & \\
\hline Total & 13 & 30.2 & 30 & 69.8 & 43 & 100 & \\
\hline
\end{tabular}

Hasil analisis menggunakan uji statistic fisherexacttestdengan nilai $p<0,05 y$ yitu 0.000 yang berarti terdapat hubungan yang signifikan antara asupan karbohidrat dengan obesitas

Tabel 18.Analisis Hubungan Antara Asupan Karbohidrat dan Obesitas Status Gizi

\begin{tabular}{ccccccccc} 
& \multicolumn{4}{c}{ Status Gizi } & \multicolumn{3}{c}{ Total } & \multirow{2}{*}{ p-value } \\
\cline { 2 - 5 } AsupanKarbohidrat & Non Obesitas & \multicolumn{2}{c}{ Obesitas } & & & \\
\cline { 2 - 6 } & $\mathrm{n}$ & $\%$ & $\mathrm{n}$ & $\%$ & $\mathrm{n}$ & $\%$ & \\
\hline Rendah & 4 & 9.3 & 1 & 2.3 & 5 & 11.6 & 0.000 \\
Tinggi & 9 & 20.9 & 29 & 67.5 & 38 & 88.4 & \\
\hline Total & 13 & 30.2 & 30 & 69.8 & 43 & 100 & \\
\hline
\end{tabular}

2. Hubungan Tingkat Pengetahuan Gizi dan Obesitas 
Hasil analisis menggunakan uji statistic fisherexacttestdengan nilai $p<0,05$, yaitu 0.004 yang berarti terdapat hubungan yang signifikan antara asupan tingkat pengetahuan gizi dengan dengan obesitas.

Tabel 19. Analisis Hubungan antara Tingkat Pengetahuan Gizi dan Obesitas

\begin{tabular}{|c|c|c|c|c|c|c|c|}
\hline \multirow{3}{*}{ Peng,Gizi } & \multicolumn{4}{|c|}{ Klasifikasi IMT } & \multicolumn{2}{|c|}{ Total } & \multirow{3}{*}{$p$-value } \\
\hline & \multicolumn{2}{|c|}{ Obesitas } & \multicolumn{2}{|c|}{ Non Obesitas } & \multirow[t]{2}{*}{$\mathrm{n}$} & \multirow[t]{2}{*}{$\%$} & \\
\hline & $\mathrm{n}$ & $\%$ & $\mathrm{n}$ & $\%$ & & & \\
\hline Baik & 9 & 21 & 5 & 12 & 14 & 33 & \\
\hline Sedang & 3 & 7 & 17 & 39 & 20 & 46 & 0.004 \\
\hline Kurang & 1 & 2 & 8 & 19 & 9 & 21 & \\
\hline Total & 13 & 30 & 30 & 70 & 43 & 100 & \\
\hline
\end{tabular}

\section{PEMBAHASAN}

\section{Karakteristik Umum Responden}

\section{a. JenisKelamin}

Berdasarkanpenelitian yang telahdilakukanrespondenberjumlah 43 orang, terdiridarilaki-lakisebanyak 21 orang (48.8\%) danperempuansebanyak 22 orang $(51.2 \%)$, danresponden yang mengalaiobesitassebanyak 30 orang $(69.8 \%)$.

\section{b. Umur}

Berdasarkanpenelitian yang telahdilakukansebagianbesarumurresponden rata-rata 16 tahundenganumur minimum 15 tahundanumurmaksimum 17 tahun . Respondenpadausia 16 tahunmemilikipersentaseobesitas yang lebihbesaryaitu $79.11 \%$ dibandingkandenganusia 15 dan 17 tahunyaituhanya $4.7 \%$ dan $16.3 \%$..

\section{Hubungan Pola Makan dengan Obesitas}

1) HubunganAsupanEnergidenganObesitas

Energi berasal dari pembakaran karbohidrat, protein, dan lemak yang dibutuhkan tubuh untuk pernafasan, bergerak atau melakukan aktifitas fisik. Jika kebutuhan energi tidak tercukupi maka kelangsungan proses di dalam tubuh menjadi teranggu (Lavie et al, 2009). Berdasarkan penelitian yang telah dilakukan menunjukkan bahwa asupan protein rata - rata responden memiliki asupan energiyang tinggi dengan status gizi obesitas yaitu sebanyak 29 orang $(67.4 \%)$ dan yang paling sedikit responden memiliki asupan energi tinggi dengan status non obesitas yaitu sebanyak 5 orang $(11.6 \%)$.

Hasilpenelitianterdapathubungan yang bermakna antara asupan energi dengan obesitas. Hasil penelitian ini sesuai dengan hasil penelitian (Restuastutiet al, 2016) yang menyaakanbahwaterdapathubunganasupanenergidanzatgizimakrodengankejadianobesitasp adaremaja di SMA Negeri 5 Pekanbaru. Penelitian lain dari Mokolensang juga meyatakan bahwa asupan energi jugasebagai salah satu faktor risiko terjadinya obesitas pada remaja di Kota Bittung.

2) HubunganAsupan Protein dengan Obesitas

Protein merupakan zat gizi yang sangat penting, karena yang paling erat hubungannya dengan proses-proses kehidupan.Protein berfungsi untuk membentuk 
jaringan baru dalam masa pertumbuhan dan perkembangan tubuh, memelihara, memperbaiki, mengganti jaringan yang rusak dan sebagai cadangan energi bila tubuh kekurangan lemak dan karbohidrat. Melalui reaksi biokimia, protein yang tidak dipakai untuk pertumbuhan dan pemeliharaan jaringan akan diubah menjadi lemak dan disimpan sebagai cadangan lemak (Sumardjo, 2008). Berdasarkan penelitian yang telah dilakukan menunjukkan bahwa asupan protein rata - rata responden memiliki asupan protein yang tinggi dengan status gizi obesitas yaitu sebanyak 28 orang $(65.1 \%)$ dan yang paling sedikit responden memiliki asupan protein tinggi dengan status non obesitas yaitu sebanyak 4 orang $(9.3 \%)$.

Hasil penelitian terdapat hubungan yang bermakna antara asupan protein dengan status obesitas .Hasil penelitian ini sesuai dengan hasil penelitian Dottir yang menyatakana dahubungan antara asupan protein denganobesitas.Penelitian serupa yang dilakukan di Kabupaten Jember menunjukkan terdapat hubungan yang antaratingkatkonsumsi protein dengan status gizi (Nurcahyani, 2014). Penelitian lain terhadapremaja SMA di Cepu, di dapatkan hasil terdapat hubungan signifikan protein dengan status gizi.

3) HubunganAsupanLemakdenganObesitas

Lemak merupakan komponen struktural dari semua sel-sel tubuh yang dibutuhkan untuk fungsi fisiologis tubuh. Lemak terdiri dari trigliserida, fosfolipid, dan sterol yang masing-masing memiliki fungsi khusus bagi kesehatan manusia. Lemak juga dapat memberikan tenaga bagi tubuh, apabila asupan lemak berlebihan, kalori yang tidak terpakai akan ditimbun dalam tubuh (Hidayat, 2008). Berdasarkanpenelitian yang telah dilakukan menunjukkan bahwa asupan protein rata-rata responden memliliki asupanlemak yang tinggidengan status giziobesitassebanyak 14 orang (32.6\%) dan yang paling sedikit responden yang memiliki asupan lemak tinggi dengan status gizi non obesitassebanyak 1 orang $(2.3 \%)$. Hasil penelitian terdapat hubungan yang bermakna antara asupan lemak dengan obesitas.Hasil penelitian inis ejalan dengan penelitiankohort yang dilakukan oleh (Gillis et al, 2004) terhadap remaja Kanada.Asupan lemak secara bermakna berhubungan dengan status gizi ( $p, 0.0001)$.

Remaja obesitas mengkonsumsi lebihbanyak total energi, lemak dan asam lemak jenuh yang lebih banyak dibandingkan remaja dengan status gizi tiakobesitas.Asupan yang berlebih in kemudian akan menentukan persentase lemak tubuh yang mengontrol aktifitas fisik.Makanan tinggi lemak mempunyai rasa yang lezat dan kemampuan mengenyangkan yang rendah, sehingga orang dapat mengkonsumsinya secara berlebihan.Kapasitas penyimpanan makro nutrient juga menentukan keseimbangan energi.Lemak mempunyai kapasitas penyimpanan yang tidak terbatas.

4) Hubungan Asupan Karbohidrat dengan Obesitas

Karbohidrat adalah salah satu zat gizi penting yang memberikan energi cukup besar bagi tubuh untuk bekerja dan berfungsi dengan baik. Konsumsi karbohidrat harus seimbang antara pemasukan dan pengeluaran energinya, bila pemasukan lebih banyak dari pengeluaran maka energi yang tidak digunakan akan disimpan di dalam tubuh dalam bentu lemak, akibatnya banyak orang yang tubuhnya menjadi obesitas karena kelebihan energi dan akan berlanjut dengan timbulnya masalah kesehatan (Graha, 2010). Berdasarkan penelitian yang telah dilakukan menunjukkan bahwa rata-rata responden memliliki asupan karbohidrat yang tinggi dengan status gizi obesitas sebanyak 29 orang (67.5\%) dan yang paling sedikit responden yang memiliki asupan karbohidrat tinggi dengan status gizi non obesitas sebanyak 9 orang (20.9\%).

Hasil penelitian terdapat hubungan yang bermakna antara asupan karbohidrat dengano besitas. Hasil penelitian ini sejalan dengan hasil penelitian (Yussacet al, 2007) yang menyatakan bahwa ada hubungan antara asupan karbohidrat dengan obesitas. Penelitian serupa yang dilakukan di Kabupaten Jember menunjukkan terdapat hubungan yang antara tingkat konsumsi karbohidrat dengan status gizi (Nurcahyani,2014). Penelitian lain terhadap 
remaja SMA di Cepu, didapatkan hasil terdapat hubungan signifikan karbohidrat dengan status gizi.

\section{KESIMPULAN}

Hubungan Tingkat Pengetahuan Gizi dengan Obesitas

Tingkat pengetahuan gizi dapat menentukan mudah tidaknya seseorang memahami manfaat gizi dalam makanan yang dikonsumsi.Konsumsi makanan yang baik di pengaruhi oleh tingkat pengetahuan gizi yang baik pula sehingga diharapkan dapat menuju status gizi yang baik. Berdasarkan penelitian yang telah dilakukan, sebagian besar responden memiliki tingkat pengetahuan yang sedang dengan jumlah 20 orang (46.5\%), tingkat pengetahuan baik 14 orang (32.6\%), dan tingkat pengeahuan kurang sebanyak 9 orang $(20.9 \%)$. Hasil penelitian yang telah dilakukan pada remaja SMA Kristen 1 Tomohon menunjukkan bahwa terdapat hubungan bermakna antara pengetahuan gizi dengan kejadian obesitas dengan nilai $p$ 0.004<0.05, Hasil penelitian ini tidak sejalan dengan penelitian Ade \& Trias (2013) yang menyatakan tidak ada hubungan antara pengetahuan gizi dengan obesitas.

\section{DAFTAR PUSTAKA}

Ade C, Nirmala D, Trias M. (2013). HubunganPolaMakan, AktifitasFisik, Sikap, Dan PengetahuanTentangObesitasDengan Status GiziPegawaiNegeriSipil Di Kantor DinasKesehatanProvinsiJawaTimur. Media Gizi Indonesia, Vol 9. No 1

Almatsier , 2010 , Prinsip Dasar Ilmu Gizi , Jakarta : Penerbit PT Gramedia Pustaka Utama .

Graha C. K. (2010). 100 Question and Answer: Kolesterol. PT Elex Media Komputindo, Jakarta, pp 147-148

Hasdianah, Siyoto, Peristyowati dkk, 2013, Gizi, Pemanfaatan Gizi, Diet, dan Obesitas, Yogyakarta: Penerbit Nuha Medika

Kussoy, Fatimawali, Kepel, (2013). Prevalensi Obesitas Pada Remaja di Kabupaten Minahasa.Jurnal e-Biomedik. Vol. 1,No 2 Juli 2013

Sediaoetama, Achmad Djaeni. (2000). Ilmu Gizi untuk Mahasiswa dan Profesi Jilid I.Jakarta : Dian Rakyat

Surioka, 2012, Penyakit Degeneratif, Yogyakarta : Penerbit Nuha Medika

Suryaputra dan Nadhiroh, Pernedaan Pola Makan dan Aktivitas Fisik Antara Remaja Obesitas dan Non Obesitas, Makara kesehatan, Vol.16.No 1, Juni 2012 